\title{
Work management as a means to adapt to constraints in farming systems: a case study from two regions in Morocco
}

\author{
Mohamed Taher Sraïri", Sanaa Bahri and Youssra Ghabiyel \\ Hassan II Agronomy and Veterinary Medicine Institute, Department of Animal Production and Biotechnology, P.O. Box 6202, \\ 10101 Madinate Al Irfane, Rabat, Morocco
}

\begin{abstract}
Two investigations were carried out to characterize how farms manage work as a means to cope with several constraints. The investigations were based on the application of the "Work Assessment" method in 44 farms, located in two regions in Morocco. A first investigation protocol was applied in 30 farms in a rainfed agricultural area with possibilities of groundwater irrigation. The study showed that very small-scale farms specialize in cattle rearing. By contrast, farms with more land and capital tend to diversify their activities, mainly toward cash crops (vegetables and fruit trees), resulting in an increased use of off-farm staff. The second research protocol consisted in the use of the "Work Assessment" method in a sample of 14 diversified family farms in a large scale irrigation scheme. Work times in each agricultural activity (livestock and crops) were quantified, distinguishing the contributions of family members and those of the off-farm workers. Altogether, the results of the two investigations confirm the crucial role of livestock production for smallholder farms' resilience, given they have almost no options in investing in cash crops. However, the limited gross margins received from cattle rearing may imply that it could have limited attractiveness for the young generations. By contrast, in larger farms, livestock is kept as a means of diversifying the sources of incomes, farmers criticizing its very limited gross margins and its relatively high needs in work. Finally, in a context of growing tensions on workers availability, it appears that work, whether assumed by family members or hired workers, is becoming an increasing source of troubles in Morocco. This may add constraints for the achievement of ambitious increases in the staple food production in the coming years.
\end{abstract}

Keywords: crop-livestock association / hired workers / work assessment method / work management

Résumé - La gestion du travail comme moyen de dépasser les contraintes dans les systèmes agraires: une étude de cas dans deux régions du Maroc. Deux recherches ont été menées afin de caractériser les usages du travail dans les exploitations agricoles comme moyen de dépasser les contraintes foncières et de capital dans les systèmes agraires. Ces recherches se sont basées sur l'application de la méthode «Bilan de Travail» dans 44 exploitations situées dans deux régions du Maroc. Une première investigation a été menée dans 30 exploitations dans une région pluviale avec des possibilités d'irrigation à partir d'eaux souterraines. L'étude a montré que les très petites exploitations se spécialisent dans l'élevage bovin. En revanche, les exploitations avec davantage de terres et de capitaux diversifient leurs activités et pratiquent des cultures de rente (fruits et légumes). Le deuxième protocole de recherche a également utilisé la méthode «Bilan de Travail» dans un échantillon de 14 exploitations agricoles situées dans un grand périmètre irrigué. Les temps de travaux de chaque activité (élevage et cultures) ont été notés, en distinguant les contributions des membres de la famille de l'agriculteur de celles des ouvriers extra-familiaux. Les résultats des deux études confirment la participation cruciale des petites exploitations dans la fourniture de lait et de viande, car elles ne disposent pas d'alternative pour investir dans des cultures à haute valeur ajoutée. Toutefois, les marges limitées de l'élevage bovin impliquent qu'il pourrait être peu attractif pour les générations à venir. À l'opposé, dans les exploitations de plus grande taille, l'élevage bovin est un moyen de diversifier les sources de revenus, en dépit des critiques qui lui sont adressées du fait de ses marges limitées et de ses besoins conséquents en travail. Au final, dans un contexte de tensions croissantes pour la

*Corresponding author: mt.srairi@iav.ac.ma 
disponibilité en main-d'œuvre agricole, il semble que le travail, aussi bien assuré par les membres des familles des agriculteurs que par des ouvriers extra-familiaux, soit devenu source de problèmes au Maroc. Cela ajoute des contraintes aux ambitieux projets d'augmentation de la production alimentaire pour les prochaines années.

Mots clés : association polyculture-élevage / gestion du travail / méthode bilan travail / travailleurs extra-familiaux

\section{Introduction}

Numerous research demonstrate the multiple advantages of mixed crop/livestock systems, with regard to their economic sustainability (Ryschawy et al., 2013) in comparison to specialized farming activities and this also applies to environmental protection, as it allows reducing the use of pesticides (Lechenet et al., 2017). However, such diversified agricultural systems imply increasing numbers of activities and tasks, which necessitate a significant involvement of work. In developing countries, even if these diversification strategies are widely adopted by family farming units, they are facing several constraints: lack of land, limited level of education, few financial means to get inputs (feed, fertilizers, etc.) and machinery to enhance crop and livestock productivity (Schiere et al., 2002). Moreover, to ensure farming system resilience and to improve the livelihoods in African rural households, work productivity has to improve (Tittonell, 2014). In fact, focusing on smallholder farms to increase feed and food production in Africa is a necessary measure, but it might not be sufficient unless the work productivity is significantly enhanced (Collier and Dercon, 2014). In addition, smallholder farms are also widely advocated as both providing opportunities for food security and also as being more appropriate for the implementation of ecologically friendly practices (Woodhouse, 2010).

Generally, in developing countries, work productivity through family farming activities remains very limited, because too many workers are trying to get steady incomes from agriculture with limited productivity due to land and capital constraints (Sraïri, 2005). In many situations of economic transition, the numbers of workers who remain within the agricultural sector is decreasing, as they prefer to shift to activities with higher wages (Tamura, 2002). These elements underline that there are growing tensions in the work market dedicated to farming activities, as questions related to work load and wages are emerging globally. Given these facts, work has become a growing concern for farming activities, particularly those with livestock (Dedieu and Servière, 2012), as it represents a heavy burden which has to be correctly remunerated and shared between farmers, the members of their families and the off-farm manpower. The study of work organization and payment in mixed crop/livestock farming systems is hence emerging as a priority research topic in many areas worldwide, as it may help understanding farms' performance and enhancing their sustainability (Lemaire et al., 2014). As a consequence, in the present paper a similar focus on work and its management will be adopted in a sample of diverse farms. The study of work load and the gross incomes from diverse crops and livestock activities will allow analyzing farmers' choices with regards to the numerous constraints they face. The hypothesis behind such an analysis of farm incomes in relation to work uses is that work management represents an opportunity to adapt to severe constraints, such as limited land and capital, volatile prices, but also demands of growing wages.

\section{Material and methods}

\subsection{Presentation of the study regions and sample}

The sample study is the result of two preliminary studies. The first one was undertaken in the Saiis rainfed area with possibilities of groundwater uses and the second one in the Gharb large scale irrigation scheme, both located in the North Western part of Morocco (Fig. 1). These two regions are considered as the most favorable for agriculture in the country, given their mild climate and their average level of annual rainfall above $500 \mathrm{~mm}$, in a country which is mainly characterized by arid to semi-arid conditions (Schilling et al., 2012). Given these natural resources, the Saiis plain and the Gharb large scale irrigation scheme constitute important supply basins of staple food, like cereals and horticultural crops. The livestock sector is also well represented in the two regions, with dual purpose herds (milk and meat simultaneously) made of Holstein and crossbred cows (local strains $\times$ Holstein cattle) and their progeny.

In the first study, the sample consisted of 30 farms, whereas in the second one it was constituted by 14 farms. The study samples were chosen to reflect a wide diversity of farming situations: mainly smallholding units but also larger ones, farms mainly with a livestock orientation, others specialized in horticulture and others with a mix of crops and livestock. The main condition was the presence of a herd within the farm. The work force available in the studied farms was also variable, as some of them relied only on family members, whereas others had to recruit offfarm workers. The average agricultural land per farm was $10 \mathrm{ha}$, fluctuating from 0 to 80 ha (Tab. 1). Thirty-nine farms had agricultural land not exceeding $20 \mathrm{ha}$. Irrigation was adopted in 23 farms, on an area below $15 \%$ of the total agricultural land. Water sources may vary from a collective network managed by a State-run office in the Gharb area, to groundwater pumped from private wells and boreholes in the Saiis plain. Almost half of the farms relied on fallow to feed their herds, and the vast majority of the farms grew forage plots: berseem clover, alfalfa, barley and oats. In addition to fodder, farmers cultivate a vast range of crops, such as cereals and pulses (mainly rainfed), sugar cane and sugar beet (in the irrigation scheme), and horticultural crops (potato, banana, beetroot, fruit trees, etc.).

Livestock mainly consists of cattle, as only twelve farms had flocks (of sheep or goats). Cows represent $72.5 \%$ of total Livestock Units (LU, defined as a standard animal of $400 \mathrm{~kg}$ of live weight), and the average milk yield delivered to collection centres is $1540 \pm 1365$ litres per cow per year. Feed for the herd is mainly based on fodder. The quantities of feed concentrates are generally increased during summer, since 


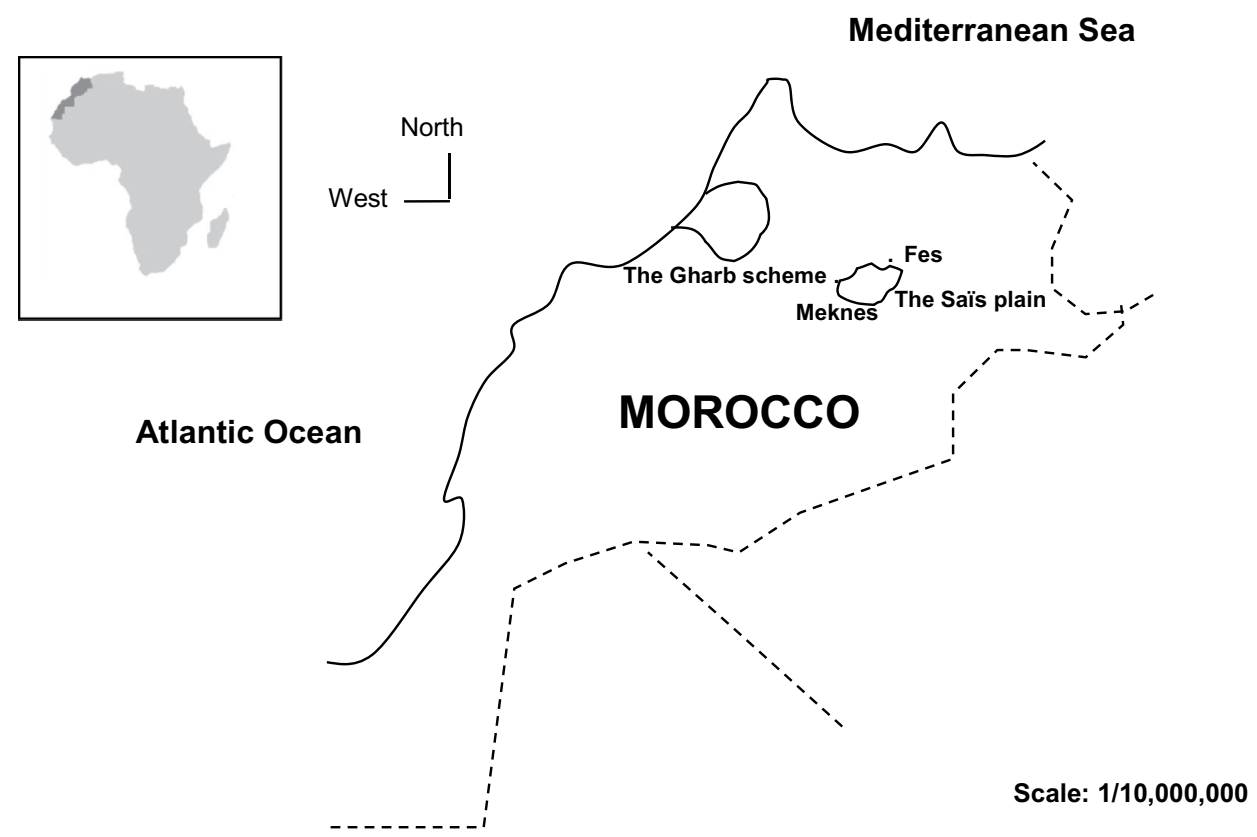

Fig. 1. Location of the study regions: the Gharb large scale irrigation scheme and the Saïs plain.

Fig. 1. Situation des régions d'étude: le périmètre de grande hydraulique du Gharb et la plaine du Sä̈s.

Table 1. Average structural characteristics and land uses in the sample farms.

Tableau 1. Paramètres structurels et assolements dans les exploitations agricoles étudiées.

\begin{tabular}{lcc}
\hline & $\begin{array}{l}\text { Mean } \pm \text { standard } \\
\text { deviation }\end{array}$ & $\begin{array}{l}\text { Minimum- } \\
\text { maximum }\end{array}$ \\
\hline Livestock units & $7.9 \pm 8.7$ & $1.4-28.6$ \\
Total arable land & $10.0 \pm 14.8$ & $0.0-80.0$ \\
Cash crops & $8.1 \pm 13.5$ & $0.0-56.0$ \\
Fodder crops & $1.7 \pm 2.4$ & $0.0-14.0$ \\
\hline
\end{tabular}

fodder availability dramatically drops (Sraïri et al., 2015) which reduces the average milk yield per cow. Twenty-four of the farms adopt "zero grazing" during the whole year because of limited land, which therefore involves regular fodder cuts (weed from neighbouring large farms) and/or the use of conserved fodder (straw, oats hay, or maize silage). In addition to feed resources from their own plots, the remaining twenty farms adopt grazing for their herds, either on cereal stubble or on alternative fodder sources, such as grass along the roads or borders.

\subsection{Methodology}

For each farm, a protocol of visits was adopted to achieve an annual follow-up. The first visit was dedicated to explaining the objectives of the study and collecting information about structural parameters of farms (i.e. agricultural land area, equipment, herd size and constitution, agricultural plots and the crops they support, etc.). On this occasion, the nature of the workers in the farm was determined: family members effectively involved in work and off-farm work force (number, gender, etc.). Monthly visits were then undertaken to quantify the duration of each task. The research adopted the principles of the 'Work Assessment' method elaborated by Dedieu et al. (1999), whose main goals aim to quantify time devoted to each on-farm activity, the annual profile of the work load and the people responsible for these activities. We added, as a further step of the analysis, the gross incomes generated by a single day of work. The data gathered from the follow-up were then analyzed in a two-way process: the first step consists of the establishment of a typology of farms specifically focusing on work uses for crops and livestock. The typology was elaborated using data with regard to farms' arable area, fodder area to total area, and the ratio of routine work (i.e. work dedicated to livestock) to total work. The second step of the study made it possible to distinguish between work devoted to livestock rearing (known as routine work which mainly consists in daily tasks devoted to the herd-milking, feeding, cleaning the barns, etc.) and work dedicated to crops (known as seasonal work). Data obtained from the interviews with farmers and the follow-up of their activities were analyzed to identify the strategies adopted with regard to the work constraints (i.e. peaks of activities, choice of crops with regard to workers availability, etc.) and its management during a whole agricultural campaign. Moreover, the gross incomes generated by work correspond to the overall sales of animal (milk, live animals) and crop products determined during a whole agricultural campaign. The gross income for each of the crops and livestock was divided by the total work devoted to each of these activities to calculate the economic efficiency of work for each activity (livestock and crop by crop) in each farm. Then, the animal gross income was divided by the routine and the seasonal work specific to herd management. Similarly, the gross incomes of each crop were divided by the seasonal volume of work it requires to determine the economic efficiency of work. 
Table 2. Characteristics of the three groups of farms with regard to work load and incomes.

Tableau 2. Caractéristiques des trois groupes d'exploitations agricoles en matière de charges de travail et de revenus.

\begin{tabular}{|c|c|c|c|c|}
\hline & Group 1 & Group 2 & Group 3 & Mean value \\
\hline Number of farms & 18 & 9 & 17 & - \\
\hline Total arable land (ha) & 2.8 & 28.3 & 14.7 & 10.0 \\
\hline Fodder land/Total arable land (\%) & $49.0^{*}$ & 11.8 & 10.0 & 26.3 \\
\hline Routine work for livestock (days per year) & 673.2 & 491.5 & 524.7 & 580.7 \\
\hline Annual income from livestock (Euros/LU) & $1005.7^{*}$ & 540.7 & 501.0 & 715.6 \\
\hline Annual income from cash crops (Euros/ha) & 558.6 & 1061.5 & 1067.3 & 858.0 \\
\hline Income from livestock/Total income (\%) & 76.2 & 49.7 & 22.6 & 50.1 \\
\hline Ratio of total work devoted to livestock (\%) & 83 & 43 & 69 & 69.4 \\
\hline
\end{tabular}

${ }^{\text {a }}$ Work autonomy: ratio of the work assumed by family members to total work volumes.

* Mean significantly different from the others on the same line $(P<0.05)$.

\section{Results}

\subsection{Typology of farms with regard to on-farm work management}

The annual work time reaches a mean value of 1030 days per farm. It increases in farms with multiple crops, varying from a minimal value of 477 days per year to a maximal one of 1887 days. The routine daily work (i.e. work needed by the herd) represents on average $59 \%$ of total work (581 days), whereas seasonal work reaches a value of 449 days $(41 \%$ of total work). These average figures are however highly variable, according to farmers' choices and the weight of livestock and crops in their production options. The contribution of family members reaches 612 days, which represents $59.4 \%$ of total work, but this figure varies according to the type of tasks: $74 \%$ of the routine work devoted to the herds is assumed by family members, whereas they only assume $29.5 \%$ of the total seasonal work devoted to crops. The average annual gross income in the studied farms was $15872 \pm 14180$ Euros. This figure is highly variable, as the work economic efficiency fluctuates a lot: $16.5 \pm 14.1$ Euros. The work efficiency in livestock appears to be rather limited, not exceeding an average income of 3.5 Euros per day. On the other hand, the gross income of work in crops appears to be much higher, as it jumps to a mean value of 35.3 Euros per day. In other words, working a same duration in cash crops generates incomes almost 10 times higher than the ones generated by livestock. However, the picture is rather complicated, as it depends on the kind of crop.

The results of the typology of farms, focusing on farms structural parameters and work uses, allowed distinguishing three types of farms, characterized as follows:

- eighteen family farms with a marked livestock orientation, because of limited land (a mean value of 2.8 ha per farm) and capital means. Fodder crops represent almost $49 \%$ of the total cultivated land, illustrating the livestock priority. This was also noticed when assessing the weight of livestock in total work time (83\%). In addition, work is mainly assumed by family members ( $73 \%$ of total work).
Livestock also generates $76 \%$ of total incomes and it showed the highest average annual income per LU value in all farms' groups (1005 Euros), whereas the income from crops is limited to 558 Euros per ha;

- nine farms with a clear orientation towards horticultural crops, and with more agricultural land (a mean value of 28.3 ha per farm) and capital than the previous ones, as they all own a tractor and a stubble-plow. Fodder crops only occupy $11 \%$ of the total cultivated land. Work time devoted to livestock only represent $33.2 \%$ of total work duration (a mean value of 1469.6 days per farm). Therefore, seasonal work devoted to crops represents $67.8 \%$ of total seasonal work volumes. The autonomy of the family vis-à-vis total work decreases to $62.1 \%$. The annual income from livestock does not exceed $20 \%$ of the total incomes (only 541 Euros per LU). On the other hand, the incomes from cash crops are better, reaching 1061 Euros per ha;

- seventeen farms which illustrate mixed rainfed crop/ livestock orientation, as both crops and livestock occupy balanced roles in income generation and work load (around $50 \%$ for both). The mean arable land per farm is almost 14.7 ha of which $10 \%$ is cultivated with fodder. Routine work for livestock is however important as it represents $69 \%$ of total work. Family members' autonomy vis-à-vis total work is rather limited, implying a significant involvement of off-farm workers. Crops are dominated by cereals and pulses, whereas horticultural crops are almost absent. The annual incomes from livestock are limited to $22 \%$ of total incomes.

A comparison of the mean values of each group enabled us to identify significant differences between these types of farms, with regard to work volumes and the origin of incomes (Tab. 2).

\subsection{The evaluation of different types of on-farm work}

The split of work activities throughout the whole agricultural campaign reveals the existence of two different 


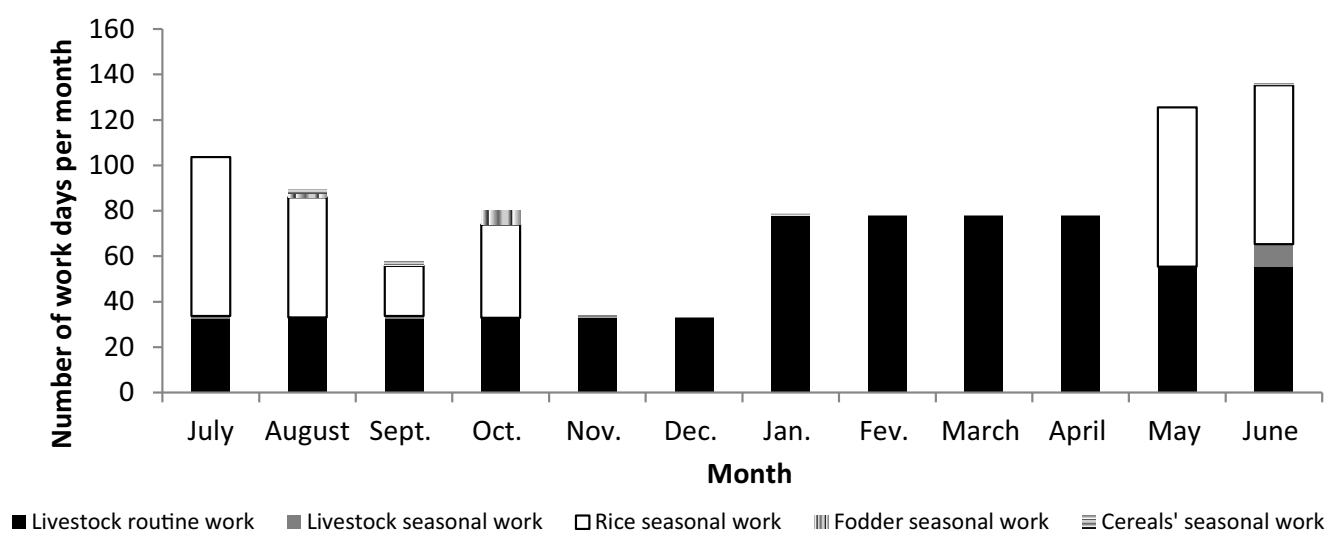

Fig. 2. Monthly variations of the number of work days in a farm with cereal/livestock association.

Fig. 2. Variations mensuelles du nombre de jours de travail dans une exploitation agricole avec une association céréales/élevage.

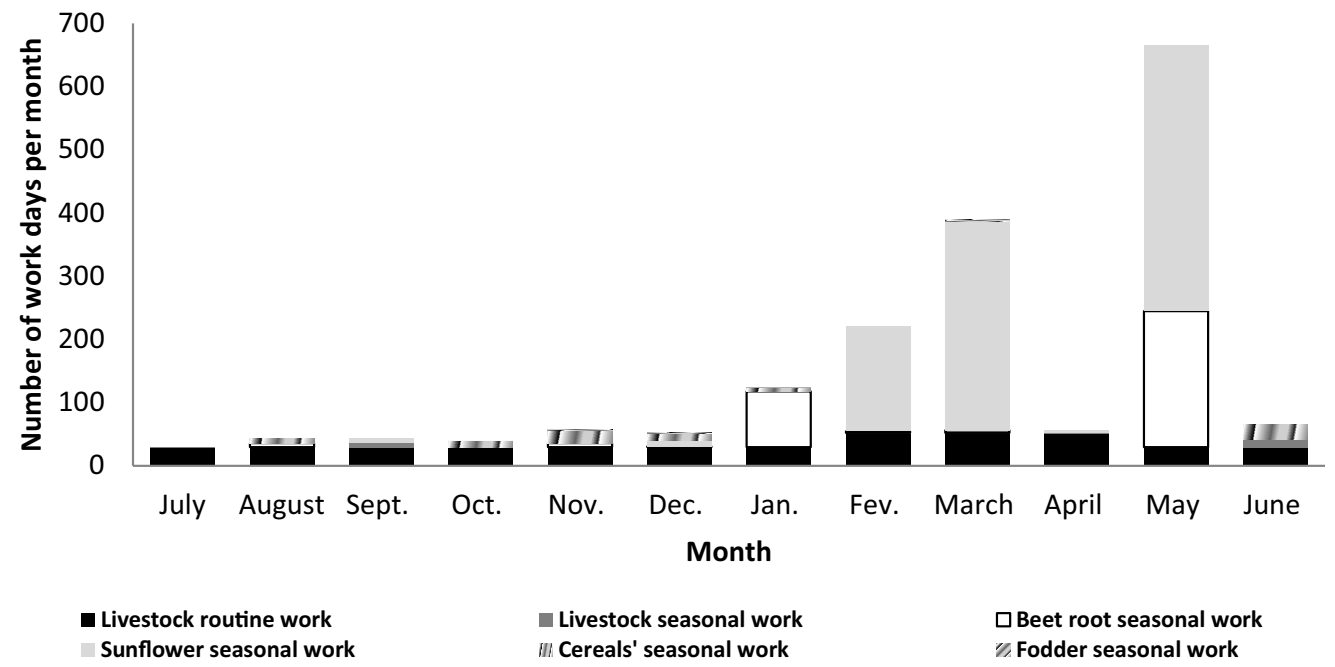

Fig. 3. Monthly variations of the number of work days in a farm with livestock and horticultural crops.

Fig. 3. Variations mensuelles du nombre de jours de travail dans une exploitation agricole avec des cultures horticoles et de l'élevage.

kinds of profiles. The first one is found in seventeen farms, whose main strategy is based on cereals (whether soft and hard wheat with or without rice) and livestock rearing. These are farms which mainly base their income on rainfed productions, and their activities are therefore highly seasonal. In fact, two of these farms also have to sow rice, because of the flood-prone nature in some areas of the study regions. In such farms, a peak of activities is determined by the rice cultivation cycle, whereas the season of reduced work load corresponds to winter (from November to February), where animals do not graze, and the essential of seasonal work is devoted to cereal cultivation, which does not necessitate important work volumes (Fig. 2).

The second profile is retrieved from the remaining twentyseven farms where livestock is associated with fodder plots, cereals and a diversified array of horticultural crops. In this second profile of work distribution throughout the year, there is a marked influence of horticultural crops on the overall work load. Periods of peak of work correspond to the practices devoted to horticultural crops such as beetroot or even sunflower, whereas the routine work necessitated by livestock is much more stable (Fig. 3).
The incomes generated by crops with regard to their work needs were significantly variable. Sugar cane might reach 221.5 Euros per single day of work, as on some occasions this crop may be sold as cuttings to neighbouring farmers, allowing a net revenue of 15500 Euros per ha. The second rank is occupied by pulses and cereals, which generate a gross income of 215.9 and 164.0 Euros per day of work. This is mainly related to their limited needs of work, as they are rainfed crops with a high degree of mechanization, generally hired, meaning relatively low costs. These rainfed crops remain crucial to generate incomes efficiently, given their limited work needs and their guaranteed public prices in comparison to horticultural products' prices volatility. This is particularly noted during favourable (rainy) years, when cereals and pulses outputs determine the overall growth of the gross economic product of the whole country's economy. Banana occupies the following rank, with a gross income of 107.1 Euros per working day, as it allows several harvests throughout the year, but it generates important levels of continuous work (irrigation, fertilization and pest treatments). The incomes generated by other horticultural crops with regard to their work 
Table 3. Gross income generated by a single working day for different cash crops.

Tableau 3. Revenu brut généré par un jour de travail dans différentes cultures de rente.

\begin{tabular}{lcl}
\hline Crop & $\begin{array}{l}\text { Number } \\
\text { of farms }\end{array}$ & $\begin{array}{l}\text { Gross income } \\
\text { (Euros/day of work) }\end{array}$ \\
\hline Sugar cane & 3 & 221.5 \\
Faba bean & 27 & 215.9 \\
Cereals & 43 & 164.0 \\
Banana & 5 & 107.1 \\
Sugar beet & 9 & 77.6 \\
Beans & 4 & 34.5 \\
Rice & 3 & 25.8 \\
Sunflower & 4 & 14.4 \\
Water melon & 6 & 10.9 \\
Maize & 17 & 5.8 \\
Peanuts & 5 & 4.2 \\
Beetroot & 6 & 1.2 \\
Potato & 7 & 0.7 \\
\hline
\end{tabular}

needs appear to be limited, and this is explained by the volatility of their farm gate prices, at a time where they all show high volumes of work, given the cropping practices they require from sowing to harvest (Tab. 3).

\section{Discussion}

The present study confirms the massive volumes of routine work necessitated by livestock, as pointed out in many previous investigations. The average value of 485 hours of routine work per year per LU is quite near to the 419 hours found in a previous research in Morocco (Sraïri et al., 2013) and to the 465 hours reported by Hostiou et al. (2012) in some family dairy farms in Vietnam. There is a significant involvement of the family members of the farmer in this routine work devoted to livestock, as they assume $74 \%$ of its total duration. Similar conclusions have also been reported in Uruguay (Dieguez et al., 2010) as rearing animals may be considered as a significant contributor to the "wealth of the poor" (Duteurtre and Faye, 2009). In addition to the routine work, livestock rearing also necessitates seasonal work (an average 3.1 days per LU), mainly consisting in fodder crop needs in maintenance and irrigation as well as storage of straw.

The results also reveal that in many cases of farms with very limited arable land and capital means, livestock remains a crucial asset for their livelihood, and accordingly, farmers choose to allocate important work time to this activity, since they have no option to grow crops on large areas and they can only rely on labor-intensive activities like livestock. In fact, in such a kind of farm, there are almost no other alternatives, as investment means for more lucrative crops are limited. Such a strategy of production is clearly illustrated by the first group of the typology of work uses identified in this study. As pointed out by Aubron et al. (2009) in the Peruvian Andes, livestock constitutes for many farmers with limited means the single opportunity of getting a regular income, through daily milk sales, though it imposes a very heavy burden of routine work. In such conditions, the use of off-farm workers may not be relevant, because of the endogenous availability of work and the limited incomes, which cannot be shared.

The results of this study also confirm the wide diversity of farming strategies in farms with limited land and capital, which represent the wide majority. These are in fact relying on higher uses of family members' work, mainly devoted to routine tasks destined to livestock, whereas the use of seasonal work dedicated to specific crops is rather limited. In previous research works in the same regions which tried to analyze livestock performances and resources uses, the same three groups of farms were identified, i.e. (1) smallholder farms involved particularly in livestock, (2) farms which mainly specialize in horticultural crops with a limited contribution of livestock, and (3) mixed crop/livestock farms (Sraïri, 2004). The present study confirms such a diversity of farming strategies and outlines the contribution of work management to cope with constraints. In fact, 35 out of the 44 studied farms clearly diversify their sources of income by a crop/livestock mix. These crops may be either horticultural or cereals and pulses. In this first group of farms, mainly constituted by smallholder units with scarce capital, livestock may represent a unique opportunity to add value to the limited assets of the farm. In farms with the dominance of horticultural crops, heavy investments in irrigation means (boreholes and/or wells, pumps, drip irrigation, etc.) as well as other equipment, such as greenhouses for banana are required. Such crops also require peaks of activities, which cannot be totally supported by the family members, involving the necessary use of off-farm workers. Such a strategy carries obvious risks, even if it allows incomes and diversification to increase. For example, it involves greater vulnerability to fruit and vegetable prices' volatility (Obayelu, 2011), in comparison to raw milk and live animals.

The second kind of crop/livestock strategy, which is found in 17 of the studied farms, relies principally on a traditional cereals/livestock association, with an important value attributed to cereals and pulses by-products (stubble and straw) to feed herds (Magnan et al., 2012). Such a strategy allows farms to benefit from complementariness between livestock and rainfed crops: manure allows soil fertility to increase and, in return, livestock may add value to crop residues, such as cereal stubble, straw, etc.

The study also reveals that the farmers' use of endogenous work is adapted to the constraints faced by their production systems. In fact, in farms with plethoric work availability with regard to land and capitals, the most important share of the family members' work will be devoted to livestock, allowing even the use of exogenous resources of fodder by grazing in nearby plots and adding value to weed from neighbouring farms. This kind of logic has already been indicated by Schiere et al. (2002), as it emphasizes the role of additional family members' work to try to ensure the sustainability of farms with limited capital. On the other hand, in farms with less availability of family members and/or with more land and capital, endogenous work might be less mobilized, and the additional production factors allow a diversification of activities by the use of exogenous workers.

The study highlights the diversity of the farmers' attitudes with regard to work management. It appears that work is used 
as a flexible adjustment variable to cope with the limitations of production factors, such as land and capital (Hostiou and Dedieu, 2011). In a context of numerous smallholding units, which are the main suppliers of staple food, such flexibility in the use of endogenous work availability is a key factor to ensure the sustainability of farming activities. However, to promote such sustainability of crop/livestock farms, further research might be needed to address the ongoing demand for better payment of work in the agricultural sector.

\section{Conclusion}

Work uses and management within 44 crop/livestock farms in Morocco show that farmers use diverse alternatives when attempting to cope with the constraints faced by their production systems. In fact, work appears to be an adjustment variable to mitigate the effects of scarce land and/or capital. For smallholder units particularly, the results confirm that massive use of family members' work for the herd is the only possibility to mitigate limited cropping opportunities and allows securing their livelihoods. However, the economic efficiency of such a work time devoted to livestock remains very limited, inducing situations of harsh work and even poverty. On the other hand, farms with more land availability and capital may choose to keep livestock and to associate it with cereals and leguminous crops. These crops are characterized by a high level of mechanization allowing a significant increase in the economic efficiency of work, as they also benefit from the manure of livestock. In such a case, more balanced options between livestock and crops are found. In fact, livestock appears to be securing incomes in cases of climatic hazards, whereas cereals and pulses may bring in significant incomes whenever sufficient and regular rainfall occurs from autumn to spring. Finally, a third group of farms choose to keep cattle and to grow horticultural crops, which are more work and capital consuming. In such a strategy, there are growing risks, due to horticultural crop prices' volatility and more needs of off-farm work. However, the incomes may grow steadily in cases of favourable market prices of the horticultural output.

The present study confirms the flexibility of work uses and management in farming systems with diverse land and capital constraints. It therefore emphasizes the need to consider work as a crucial variable in the proxy of farm performances, to enhance farming system diversity and promote the ecosystem services of the agricultural sector. Given the ongoing tensions in the work market, due to growing demand for better wages in rural areas, work within family farming systems will surely necessitate sound study approaches. It may require specific research protocols to optimize work uses in a network of farms and improve its economic efficiency, to ensure better livelihoods in rural areas.

Acknowledgements. This research was carried out in the frame of the Crop Livestock Integration in the MEDiterranean project (CLIMED). The authors would like to thank farmers for their collaboration during the study of their practices.

\section{References}

Aubron C, Cochet H, Brunschwig G, Moulin CH. 2009. Labor and its productivity in Andean dairy farming systems: a comparative approach. Human Ecology 37: 407-419.

Collier P, Dercon S. 2014. African agriculture in 50 years: smallholders in a rapidly changing world? World Development 63: 92-101.

Dedieu B, Servière G. 2012. Vingt ans de recherche-développement sur le travail en élevage : acquis et perspectives. INRA Productions Animales 25: 85-100.

Dedieu B, Laurent C, Mundler P. 1999. Organisation du travail dans les systèmes d'activités complexes : intérêt et limites de la méthode Bilan Travail. Economie Rurale 253: 28-35.

Dieguez F, Morales H, Cournut S. 2010. La méthode Bilan Travail pour l'approche du fonctionnement des élevages extensifs uruguayens. Cahiers Agricultures 19: 316-322.

Duteurtre G, Faye B. 2009. L'élevage, richesse des pauvres. Versailles (France) : Quæ.

Hostiou N, Dedieu B. 2011. A method for assessing work productivity and flexibility in livestock farms. Animal 10: 1-11.

Hostiou N, Khanh PD, Duteurtre G, Binh VT, Dedieu B. 2012. Relationships between work organization and size of dairy farms: a case study based in Vietnam. Tropical Animal Health and Production 44: 1709-1716.

Lechenet M, Dessaint F, Py G, Makowski D, Munier-Jolain N. 2017. Reducing pesticide use while preserving crop productivity and profitability in arable farms. Nature Plants 3: 17008. DOI: 10.1038/ nplants.2017.8.

Lemaire G, Franzluebbers A, de Faccio Carvalho PC, Dedieu B. 2014. Integrated crop-livestock systems: strategies to achieve synergies agricultural production and environmental quality. Agricultural Ecosystems and Environments 190: 4-8.

Magnan N, Larson DM, Taylor JE. 2012. Stuck on stubble? The non-market value of agricultural by-products for diversified farmers in Morocco. American Journal of Agricultural Economics 94: 1055-1069.

Obayelu AE. 2011. Cross-countries analysis of rising food prices: policy responses and implications on emerging markets. International Journal of Emerging Markets 6: 254-275.

Ryschawy J, Choisis N, Choisis JP, Gibon A. 2013. Paths to last in mixed crop-livestock farming: lessons from an assessment of farm trajectories of change. Animal 7: 673-681.

Schiere JB, Ibrahim MNM, van Keulen H. 2002. The role of livestock for sustainability in mixed farming: criteria and scenario studies under varying resource allocation. Agricultural Ecosystems and Environments 90: 139-153.

Schilling J, Korbinian PF, Hertig E, Scheffran J. 2012. Climate change, vulnerability and adaptation in North Africa, with focus on Morocco. Agricultural Ecosystems and Environments 156: $12-26$.

Sraïri MT. 2004. Typologie des systèmes d'élevage bovin laitier au Maroc en vue d'une analyse de leurs performances. Thèse de doctorat en Sciences agronomiques et ingénierie biologique. Belgique: Faculté universitaire des Sciences agronomiques de Gembloux, 200 p. https://tel.archives-ouvertes.fr/tel-00423512/document.

Sraïri MT. 2005. Ingénierie agronomique et développement des exploitations familiales agricoles dans les pays du Sud : réflexions à partir du cas marocain. Cahiers Agricultures 14: 485-491.

Sraïri MT, Bahri S, Kuper M. 2013. Le travail et sa contribution aux stratégies d'adaptation de petites exploitations agricoles familiales mixtes d'élevage bovin/polyculture au Maroc. Biotechnologies, Agronomie, Société et Environnement 17: 463-474. 
Sraïri MT, Sannito Y, Tourrand JF. 2015. Investigating the setbacks in conventional dairy farms by the follow-up of their potential and effective milk yields. Iranian Journal of Applied Animal Sciences 5: 255-264.

Tamura R. 2002. Human capital and the switch from agriculture to industry. Journal of Economics and Dynamics Control 27: 207-242.
Tittonell P. 2014. Livelihood strategies resilience and transformability in African agroecosystems. Agricultural Systems 126: 3-14.

Woodhouse P. 2010. Beyond industrial agriculture? Some questions about farm size, productivity and sustainability. Journal of Agrarian Change 10: 437-453.

Cite this article as: Sraïri MT, Bahri S, Ghabiyel Y. 2018. Work management as a means to adapt to constraints in farming systems: a case study from two regions in Morocco. Cah. Agric. 27: 15007. 